\title{
A New Design of a Lead-Acrylic Shield for Staff Dose Reduction in Radial and Femoral Access Coronary Catheterization
}

\section{Eine neuartige Bleiacrylglas-Scheibe zur Reduktion der Strahlenexpo- sition des medizinischen Personals bei Herzkatheteruntersuchungen}

Authors

Affiliations
H. Eder ${ }^{1}$, M. C. Seidenbusch², M. Treitl' ${ }^{2}$ P. Gilligan ${ }^{3}$

Department of Radiation Protection, formerly: Bavarian Office for Occupational Health und Safety

2 Institute for Clinical Radiology, Clinical center of the Ludwig Maximilians University Munich, Germany

Medical Physics, Mater Private Hospital, Dublin, Ireland

\author{
Key words \\ coronary angiography \\ - radiation safety \\ - physics \\ - technical aspects
}

received 28.11.2014 accepted 21.4.2015

Bibliography

Dol http://dx.doi.org/ 10.1055/s-0034-1399688

Published online: 17.6 .2015

Fortschr Röntgenstr 2015; 187:

915-923 @ Georg Thieme

Verlag KG Stuttgart · New York . ISSN 1438-9029

\section{Correspondence}

Dr. Michael C. Seidenbusch Kinderradiologie, Institut für Klinische Radiologie

Lindwurmstr. 4

80337 München

Germany

Tel.: ++ 49/89/4 40057840

Fax: ++49/89/440 057822

michael.seidenbusch@med.

uni-muenchen.de

\section{Zusammenfassung \\ $\nabla$}

Ziel: Der Strahlenschutz des medizinischen Personals bei Herzkatheteruntersuchungen und koronaren Interventionen erfolgt heute in der Regel durch die Anwendung einer BleiacrylglasScheibe kombiniert mit einem am Tisch montierten Unterkörperschutz. Ortsdosismessungen zeigten jedoch, dass diese Anordnung verbesserungsbedürftig ist.

Material und Methoden: Folgende Szenarien wurden hinsichtlich der Exposition des Personals unter Verwendung eines anthropomorphen Phantomes untersucht: a) Vergrößerung der Bleiacrylglas-Scheibe b) Ergänzung der Bleiacrylglas-Scheibe mit einem flexiblen Bleilamellenvorhang auf der Unterseite; c) Verwendung abschirmender Patientenauflagen. Zur Visualisierung der Ergebnisse wurden Monte-Carlo-Simulationen durchgeführt.

Ergebnisse: Die Anwendung eines zusätzlichen, auf der Körperoberfläche des Patienten aufliegenden, flexiblen Bleilamellenvorhanges vermindert die Ortsdosisleistung am Untersucherstandort im Vergleich zur Schutzscheibe ohne Lamellenvorhang um bis zu $(87,5 \pm 7,1) \%$. Die kombinierte Verwendung von Bleilamellenvorhang und Patientenauflage ermöglicht eine Reduktion der Ortsdosisleistung am Untersucherstandort um bis zu $(90,8 \pm 7) \%$. Analoge Ergebnisse ließen sich für das in unmittelbarer Nähe des Untersuchers anwesende Assistenzpersonal erzielen. Darüber hinaus führt die vergrößerte Scheibe zu einem verbesserten Schutz der Kopfregion von großen Untersuchern.

Schlussfolgerung: Die zusätzliche Verwendung eines flexiblen Bleilamellenvorhangs verbessert den Strahlenschutz des Untersuchers und insbesondere auch jener Körperbereiche, die von der Röntgenschutzkleidung nicht oder nur unzureichend bedeckt sind, wie z.B. Kopf und Augenlinsen. Dies ist besonders wichtig angesichts der

\section{Abstract \\ $\nabla$}

Purpose: Today's standard radiation protection during coronary angiography and percutaneous coronary interventions is the combined use of lead acrylic shields and table-mounted lower body protection. Ambient dose measurements, however, have shown that these protection devices need improvement.

Materials and Methods: Using an anthropomorphic physical phantom, various scenarios were investigated with respect to personnel exposure: a) enlarging the shield b) adding a flexible protective curtain to the bottom side of the shield, and c) application of radioprotective patient drapes. For visualization of the dose reduction effect, Monte Carlo simulations were performed.

Results: The flexible curtain in contact with the patient's body reduces the ambient dose rate at the operator's position by up to $(87.5 \% \pm 7.1)$ compared to the situation with the bare shield. The use of both the flexible curtain and the patient drape reduces the ambient dose rate by up to $(90.8 \% \pm 7)$. Similar results were achieved for the assisting personnel when they were positioned next to the operator. In addition, the enlarged shield provides better protection of the head region of tall operators.

Conclusion: Adding a flexible protective curtain to the bottom side of the shield can protect operators from high doses, especially for body parts which are not protected by lead aprons, e.g. head, and eye lenses. This may be important with respect to lower dose limits for eye lenses in future. The protective effect in real-life working conditions is still being evaluated in an ongoing clinical study.

Key Points:

- Lead acrylic shields need improvement for a better protection of head and eye lenses.

- An additional flexible lead curtain at the bottom of the shield can considerably reduce the operator dose. 
verschärften Grenzwertempfehlungen für die Augenlinse. Die Schutzwirkung unter realen klinischen Bedingungen wird derzeit in einer weiteren Studie untersucht.

Kernaussagen:

- Bleiacrylglasscheiben erfordern Verbesserungen, um einen besseren Schutz für Kopf und Augen zu erreichen.

- Ein zusätzlicher flexibler Schutzvorhang unter der Scheibe kann die Körperdosen des Operateurs deutlich senken.

- Bei Verwendung des Zusatzvorhangs kann leichtere Schutzkleidung getragen werden.

- Spezieller Augenschutz ist bei den meisten Anwendungen nicht mehr erforderlich.
- Using the additional lead curtain, lighter protection clothing can be worn.

- Special eye protection may be no longer needed in most applications.

Citation Format:

- Eder H, Seidenbusch MC, Treitl M et al. A New Design of a LeadAcrylic Shield for Staff Dose Reduction in Radial and Femoral Access Coronary Catheterization. Fortschr Röntgenstr 2015; 187: 915-923

\section{Introduction \\ $\nabla$}

In interventional cardiology and radiology, the increasing occupational exposure of operators should be focused on more rigorously since the duration and frequency of radiology-assisted interventions tend to be on the rise. Within an interventional department special procedures are frequently performed by a few specialists [1 - 5], and these procedures often lead to high cumulated staff doses. Sometimes the personnel dose limits defined in national regulations, e.g. the German Röntgenverordnung [6], can be exceeded. The wearing of protective aprons and thyroid collars is widespread but head (especially eye lenses), arms, hands and shoulder joints often remain unprotected. Especially the eye lens doses have to be considered. Recently performed investigations of operator lens exposure revealed that the recommended lens dose limit of $20 \mathrm{mSv} /$ year stated by the International Commission on Radiation Protection (ICRP) [7] and implemented in the EURATOM directive [8] is frequently exceeded in practice $[9,10]$. National regulations, e.g. in Germany, therefore stipulate engineered technical solutions for the protection of staff [11].

At present, lead acrylic shields combined with table-mounted lower body protection - both having a lead equivalence value of $0.5 \mathrm{~mm}$ - are state of the art and commonly installed $[12,13]$. These shields should reduce scatter radiation doses nominally by about $98 \%$ compared to the scenario without a shield. Contrary to this, our dose measurements at the operator's position show dose reductions by only $70 \%$ to $80 \%$. The physics of this contradiction can easily be explained: the protective shield even though it touches the skin of the patient - cannot stop the Compton scatter radiation from penetrating through the surface tissue of the patient. This effect results in a limitation in the protective properties of the shield ( $\bullet$ Fig. 1 ). Within the ORAMED project, Donadille et al. [9] interpret this adverse effect as "inappropriate use and non-optimized design". As shown there, an optimized protective scenario cannot be achieved solely by the use of an upper and lower body shield. For an adequate solution, additional protective patient drapes are needed. These drapes prevent the local scattered radiation from escaping from the patient's body. In practice these drapes have been applied either in isolation or in combination with shields [14-16].

In the study presented here we investigated special technical solutions to optimize protection for the operator and assistants. We focused especially on a novel protection shield rigged with a flexible curtain of absorbing lamellae simultaneously applied with/ without an absorbing patient drape, which can be positioned in a sterile cover on top of the patient and can quickly be removed. The curtain and drape should stop the escape of Compton scatter radiation through the tissue underneath the lower edge of the shield. The procedures were evaluated by physical measurements using an anthropomorphic phantom. The reduction of head doses was visualized by Monte Carlo simulations.

\section{Methods \\ $\nabla$}

\section{Lead acrylic shields}

Shield " $\mathrm{A}$ " is commonly in use in the most interventional facilities and has a size (width $\times$ height) of $60 \times 76 \mathrm{~cm}^{2}$. It was compared to a newly designed larger shield "B" with dimensions of $78 \times 90 \mathrm{~cm}^{2}$ ( $\bullet$ Fig. 2). Both shields feature the same lead acrylic material and identical lead equivalence value (LEV) of $0.5 \mathrm{~mm}$ from 50 to $150 \mathrm{kV}$. The intention of larger shield B was to facilitate the protection of the head of operators with a body height of up to $2 \mathrm{~m}$ as well as the protection of co-workers standing nearby the operator. Both shields were mounted on a ball-joint and therefore could be adapted to most applications encountered clinically.

New shield B is characterized by two curved gaps; the wider one is predominantly designed for adapting to the patient's body and the smaller one for allowing the arm of the patient to pass through, e.g. within radial access. The gaps are covered by a sliced flexible

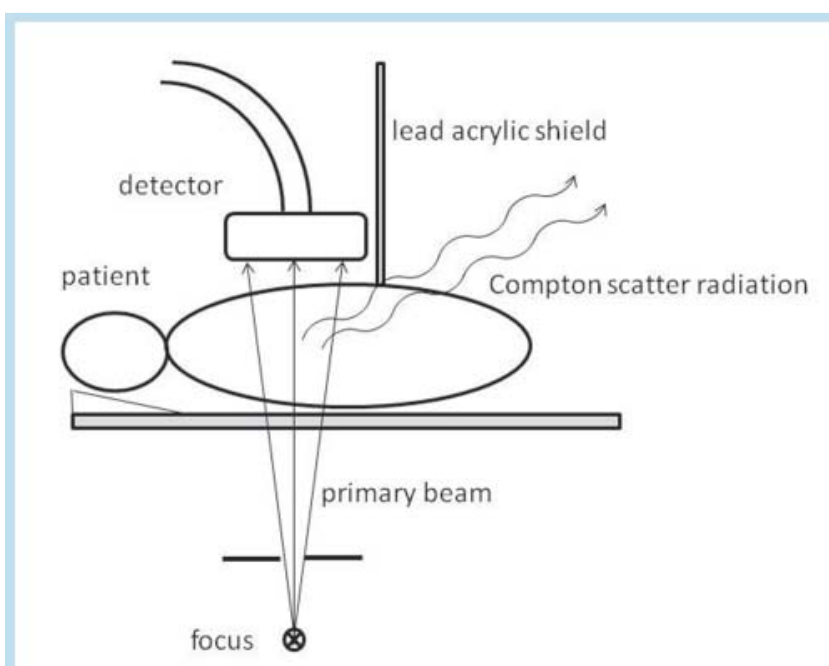

Fig. 1 Compton scatter radiation generated within the irradiated tissue of the patient can penetrate underneath the shield even though the shield contacts the patient's surface.

Abb. 1 Im Patientengewebe entsteht Compton-Streustrahlung, die unterhalb des Strahlenschutzschildes entweichen kann, obwohl das Schild in Kontakt mit der Patientoberfläche steht. 


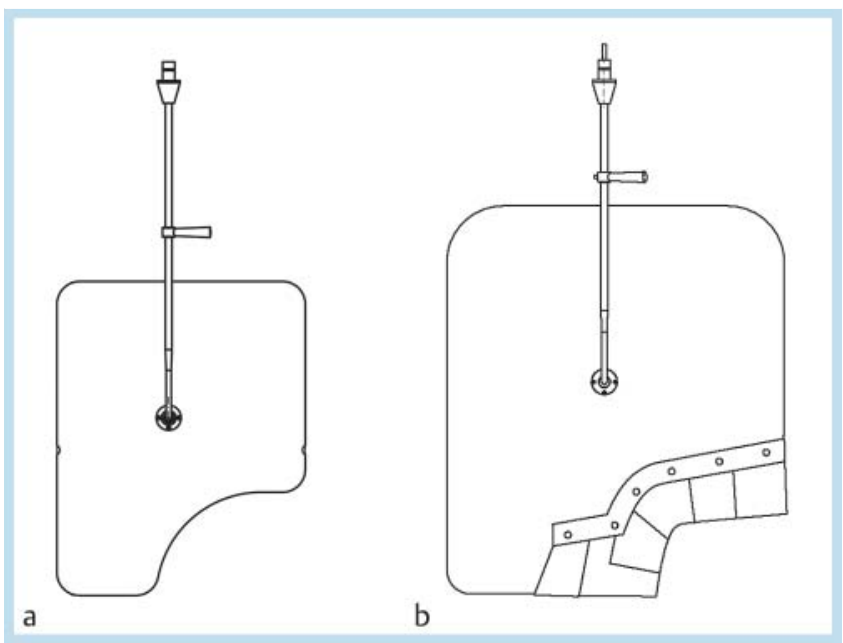

Fig. 2 a commonly used shield type A, b new enlarged shield type B with flexible shielding curtain and additional arm gap.

Abb. 2 a üblicherweise eingesetztes Schild Typ A, b neues, vergrößertes Schild Typ B mit flexiblem Lamellenvorhang und zusätzlichem Armausschnitt.

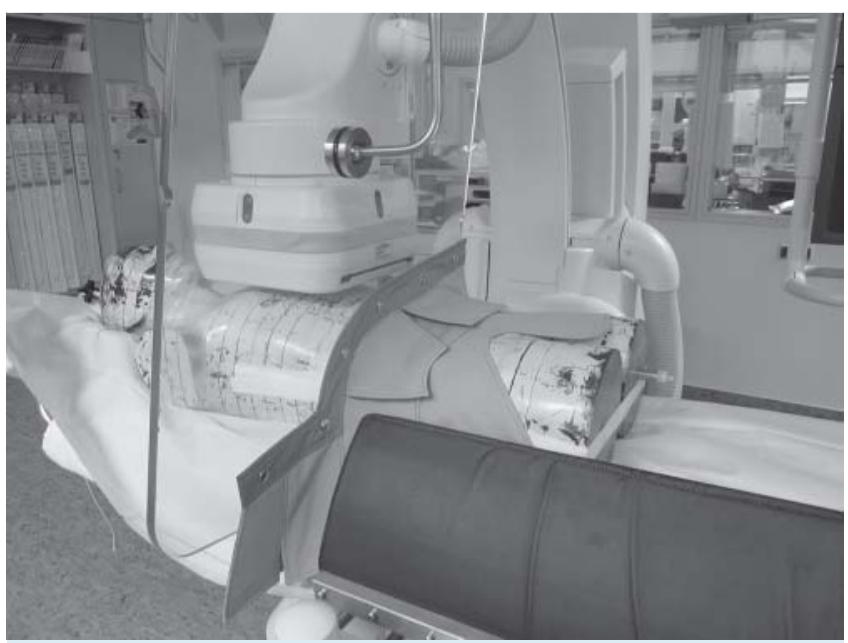

Fig. 3 Setting for the measurements: Alderson-Rando phantom and large shield B with lamellae-curtain positioned on the patient table. Additional drape DFA with functional gap for femoral access. The table side protection with tabletop extension (foreground) was in position during the whole measurement process.

Abb. 3 Messanordnung: Alderson-Rando-Phantom und großes Schild B mit Lamellenvorhang, positioniert am Patiententisch. Der Tisch-Seitenschutz und die Aufsatzblende waren während der gesamten Messungen in Position.

curtain with overlapping lamellae having an average length of $13 \mathrm{~cm}$ ( Fig. 3). The lamellae should adapt to the patient's surface on half of their length. The lead equivalence value of the absorbing lamellae is $0.5 \mathrm{~mm}(50-150 \mathrm{kVp})$. This should be sufficient to stop the scatter radiation penetrating through the tissue underneath the shield. A custom designed pattern of the lamellae should avoid gaps when the lamellae touch the body. The new shield can be used for femoral as well as for radial access.

\section{Patient drapes}

Combined with the shield, the following additional protective effects of patient drapes with a lead equivalence value of $0.5 \mathrm{~mm}$ (50 to $150 \mathrm{kVp}$ ) were investigated:

- Drape for femoral access (DFA) $75 \times 32 \mathrm{~cm}$ with functional gap (० Fig. 3)

- Drape for radial access (DRA) $75 \times 39 \mathrm{~cm}$ without gap

- Drape type "Utech" ranging from the costal arch down to the middle of the thighs

The DFA and DRA drape types were designed for multiple use and are sterilizable. Hence, they can be positioned on top of the sterile patient covering and can quickly be removed, e.g. in emergency situations. Compared to the single use drapes which must be disposed of after usage, the multiple use sterilizable drapes save basic material and hence have ecological advantages. For femoral access, the DFA drape type shows a gap near the femoral port. The DRA drape was designed especially for the radial access without a femoral gap. Both drapes are designed to avoid interference with the imaging system, especially if the C-arm is angulated to the LAO direction. Since previous comparative measurements did not show a significant difference between the DRA and DFA drapes, we performed the measurements for this paper generally using the DFA drape. The drape extending caudal to the middle of the thighs was propagated for a long time ago by Utech [17]. This drape has a rectangular cutout in the region of the femoral port and has a slit for fast removal.

\section{Investigated scenarios}

The operator's and assistant's exposure was determined by ambient dose rate measurements. Routine clinical conditions of coronary interventions were simulated. Several scenarios with protective shields and drapes were tested:

0 . Without shield

1. Shield A without any other protection items

2. Shield B (enlarged shield A) without any other protection items

3. Shield B with DFA drape

4. Shield B with protective curtain

5. Shield B with protective curtain and DFA drape ( $\bullet$ Fig. 3 )

6 . Shield B with protective curtain and "Utech" drape type

All measurements were performed with complete tableside protection ( $0.5 \mathrm{~mm} \mathrm{~Pb}$ lead equivalence value, $50-150 \mathrm{kVp}$ ), reaching from $5 \mathrm{~cm}$ above the floor up to the anterior surface of the phantom. Hence dose measurements below the edge of the table were not considered.

\section{Measurements with the physical phantom}

The measurements were conducted on a C-arm "AXIOM Artis" (Siemens Healthcare, Germany) run in the fluoroscopic mode with 6 pulses per second. The total filtration was $2.5 \mathrm{~mm}$ $\mathrm{Al}+0.1 \mathrm{~mm} \mathrm{Cu}$. The patient's upper body was simulated by an Alderson-Rando phantom type 275 NPL. A postero-anterior (pa) beam geometry with a focus-detector distance of $90 \mathrm{~cm}$ and a field size of $16 \times 16 \mathrm{~cm}^{2}$ in the detector plane was applied. The central beam was positioned with respect to the heart region. The automatic dose rate control was adjusted to a pulse current of $249 \mathrm{~mA}$ and a tube voltage of $76 \mathrm{kVp}$. These values match an average patient of normal weight.

For the ambient dose rate measurements, we used a dosimeter "Babyline 81" (Nardeux, France) with tissue-equivalent cap, calibrated in "photon dose equivalent" $H_{x}(\mu S v / h)$. To convert this quantity to the new quantity "ambient dose equivalent" $H^{*}[10]$, the measured dose values were multiplied by a factor of 1.3 
[18]. This factor was based on an estimated mean energy of the scattered radiation in the range of $35-40 \mathrm{keV}$. The lower limit of the measurement range of the Babyline 81 is specified by the manufacturer to be $2 \mu \mathrm{Sv} / \mathrm{h}$. The mean standard deviation calculated from 10-fold repetitions of ambient dose rate measurements with repositioning of the dosimeter at different locations and restarting of the irradiation resulted in $\sigma=7 \%$. This value was adopted for all ambient dose rate measurements.

\section{Position of operator and assistant}

We measured the ambient dose rate profiles along the (virtual) vertical axis of the operator and the assistant from $70 \mathrm{~cm}$ up to $200 \mathrm{~cm}$ above the floor. The dosimeter was fixed to a vertical stand with a centimeter scale. The vertical axis of the operator was located $60 \mathrm{~cm}$ caudal to the central beam and $45 \mathrm{~cm}$ lateral to the centerline of the table. In the case of the assistant, the vertical axis was located $120 \mathrm{~cm}$ caudal to the center beam and $45 \mathrm{~cm}$ lateral to the table centerline.

Referring to the vertical axis of the operator, we measured the horizontal ambient dose profile $160 \mathrm{~cm}$ above the floor. The horizontal reference axis expands from $-80 \mathrm{~cm}$ to $+70 \mathrm{~cm}$ rectangular to the table centerline with origin at the vertical axis of the operator.

Table 1 Parameters for the MC simulation.

Tab. 1 Parameter für die MC-Simulation.

\begin{tabular}{|ll}
\hline simulation volume & $2.4 \cdot 2.4 \cdot 3.0 \mathrm{~m}^{3}$ \\
\hline number of photon histories & $1.0 \cdot 10^{9}$ \\
\hline secondary electron cut-off energy & $0.5 \mathrm{MeV}$ \\
\hline voxel size & $1.0 \cdot 1.0 \cdot 10.0 \mathrm{~cm}^{3}$ \\
\hline dose unit & absorbed dose (Gy) \\
\hline extracorporal medium & ICRU air \\
\hline medium of patient and operator & homogeneous ICRU soft tissue \\
\hline X-ray beam quality & $76 \mathrm{kVp}$, total filtration $2.5 \mathrm{Al}+0.1 \mathrm{Cu}$ \\
\hline cross-section data & 521 icru.pegs4dat \\
\hline
\end{tabular}

\section{Monte Carlo Simulation}

For visualization of the operator's exposition in the upper body and head region, Monte Carlo simulations were performed for the scenarios (2) and (3) using the PC program EGS-Ray [19]. This program is based on the EGS4 code [20] and allows calculation of the spatial dose distributions under the given beam geometries and radiation qualities. The algorithm determines the absorbed dose in each voxel of the computational volume using the KERMA approximation (MC data see $\bullet$ Table 1 ).

For the Monte Carlo simulations, the physical patient trunk phantom and the examiner's body were approximated through homogeneous elliptical cylinders consisting of ICRU soft tissue without considering bone, inner organs and tissues. The heads of the patient and operator were approximated by homogeneous ellipsoids. The patient was positioned horizontally on the table, as described in section 2.3.2. The operator was standing upright near the patient, facing the monitors on the opposite side of the table. The photon spectrum was calculated from the parameters of the beam quality (X-ray tube voltage $76 \mathrm{kVp}$, total filtration $2.5 \mathrm{~mm} \mathrm{Al}$ $+0.1 \mathrm{~mm} \mathrm{Cu}$, anode angle $15^{\circ}$ ) in accordance with the theory of Birch and Marshall [21]. The computation was based on $10^{9}$ single photon histories.

\section{Results \\ $\nabla$}

\section{Phantom measurements}

- Fig. 4 displays the results from the ambient dose rate measurements for 7 scenarios and includes the comparison of shield A with shield $\mathrm{B}$, both without any additional protection devices. Also, the scenarios without any shield and the scenarios with shield B and additional protective means (protective curtain, drapes) are shown here.

An overview of the main results of the dose reduction resulting from the different scenarios is presented in 0 Table 2, $\odot$ Fig. 5.

The best result was achieved from a combination of both components: drape and curtain (scenario 5). However, if only either the drape alone or the curtain alone is combined with the new shield,

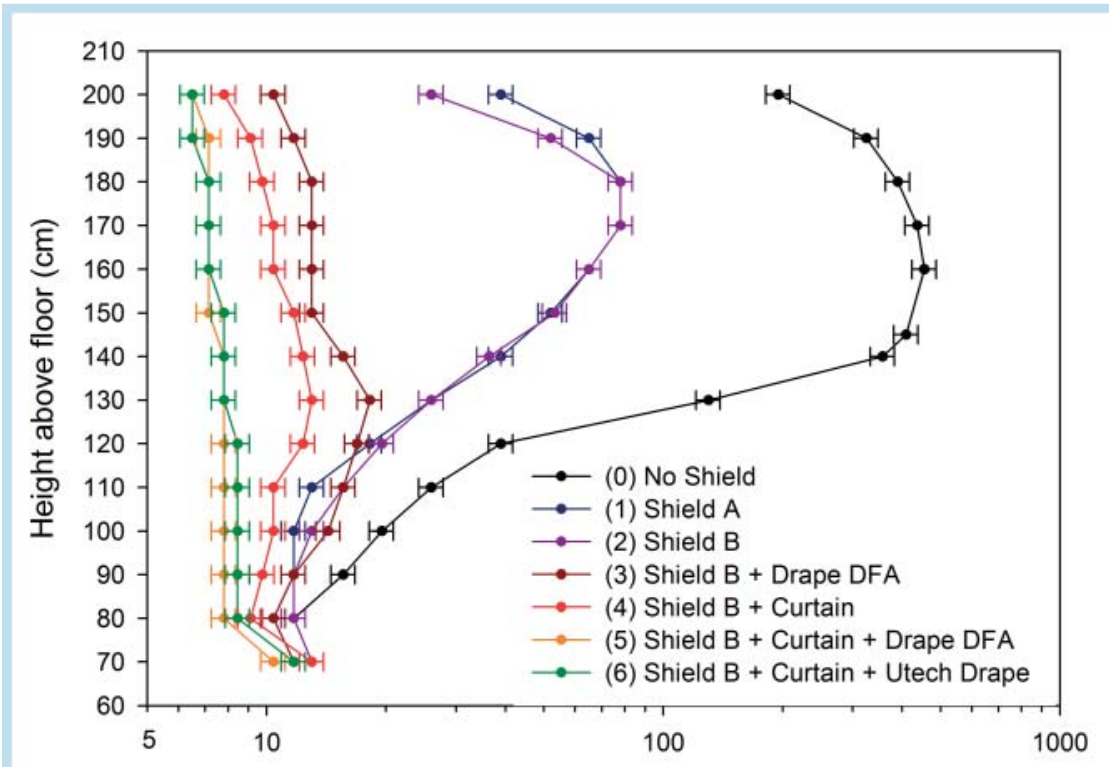

Fig. 4 Ambient dose rates at the (virtual) vertical axis of the operator for several scenarios using shields $A$ and $B$ and several combinations of the protective curtain with or without DFA and "Utech" drapes, respectively. Standard deviations are indicated.

Abb.4 Ortsdosisraten auf der (virtuellen) Vertikalachse des Operateurs für verschiedene Szenarien mit Schild A bzw. Schild B und verschiedenen Kombinationen aus Lamellenvorhang mit und ohne Patientendecke Typ DFA bzw. Typ Utech. Die Standardabweichungen sind angegeben.

Ambient dose equivalent rate $\dot{H}^{*}(10)$ at the operator's vertical axis $(\mu \mathrm{Sv} / \mathrm{h})$ 
Table 2 Measured ambient dose reduction vs. height above the floor through several protective scenarios using the new shield B together with a protective curtain and a patient drape type DFA, respectively. The numbers are based on the present standard scenario 1 (shield A without any other protection add-ons). Vertical axis of measuring was located $60 \mathrm{~cm}$ caudal to the center beam and $45 \mathrm{~cm}$ lateral to the centerline of the table (operator) and $120 \mathrm{~cm}$ caudal/45 cm lateral (assistant)

Tab. 2 Gemessene Ortsdosisreduktion in Abhängigkeit von der Höhe über Boden für verschiedene Schutzszenarien unter Benutzung von Schild B zusammen mit dem Schutzvorhang bzw. einer Patientendecke Typ DFA. Die Zahlen-Bezugsbasis ist das derzeitige Szenario 1 (Schild A ohne Zusatz). Die vertikale Achse des Untersuchers befindet sich $45 \mathrm{~cm}$ lateral von der Tischmitte und $60 \mathrm{~cm}$ caudal vom Zentralstrahl, bzw. $120 \mathrm{~cm}$ caudal/45 cm lateral für den Standort Assistenz.

\begin{tabular}{|c|c|c|c|c|}
\hline \multirow{3}{*}{$\begin{array}{l}\text { height above } \\
\text { floor }(\mathrm{cm})\end{array}$} & \multicolumn{4}{|c|}{ dose reductions vs. scenario $1 \pm$ s.d. (\%) } \\
\hline & operator & & & assistant \\
\hline & scenario 2: shield B & $\begin{array}{l}\text { scenario 4: shield B } \\
\text { with curtain }\end{array}$ & $\begin{array}{l}\text { scenario } 5 \text { : shield B } \\
\text { with curtain plus drape DFA }\end{array}$ & $\begin{array}{l}\text { scenario } 5 \text { : shield B } \\
\text { with curtain plus drape DFA }\end{array}$ \\
\hline 80 & \multirow{6}{*}{$\begin{array}{l}\text { no difference with } \\
\text { respect to scenario } 1\end{array}$} & $22.2 \pm 8.9$ & $33.4 \pm 9.0$ & $27.8 \pm 8.6$ \\
\hline 100 & & $20.0 \pm 9.0$ & $40.0 \pm 8.2$ & $75.0 \pm 7.2$ \\
\hline 120 & & $32.2 \pm 8.3$ & $57.2 \pm 7.5$ & $68.0 \pm 7.3$ \\
\hline 140 & & $68.4 \pm 7.4$ & $80.0 \pm 7.2$ & $60.7 \pm 7.5$ \\
\hline 160 & & $84.0 \pm 7.1$ & $89.0 \pm 7.0$ & $92.5 \pm 7.0$ \\
\hline 180 & & $87.5 \pm 7.1$ & $90.8 \pm 7.0$ & $90.9 \pm 7.0$ \\
\hline 190 & $20.1 \pm 8.9$ & $86.0 \pm 7.1$ & $89.0 \pm 7.0$ & $87.0 \pm 7.1$ \\
\hline 200 & $33.0 \pm 8.4$ & $80.0 \pm 7.3$ & $83.4 \pm 7.2$ & $75.2 \pm 7.2$ \\
\hline
\end{tabular}

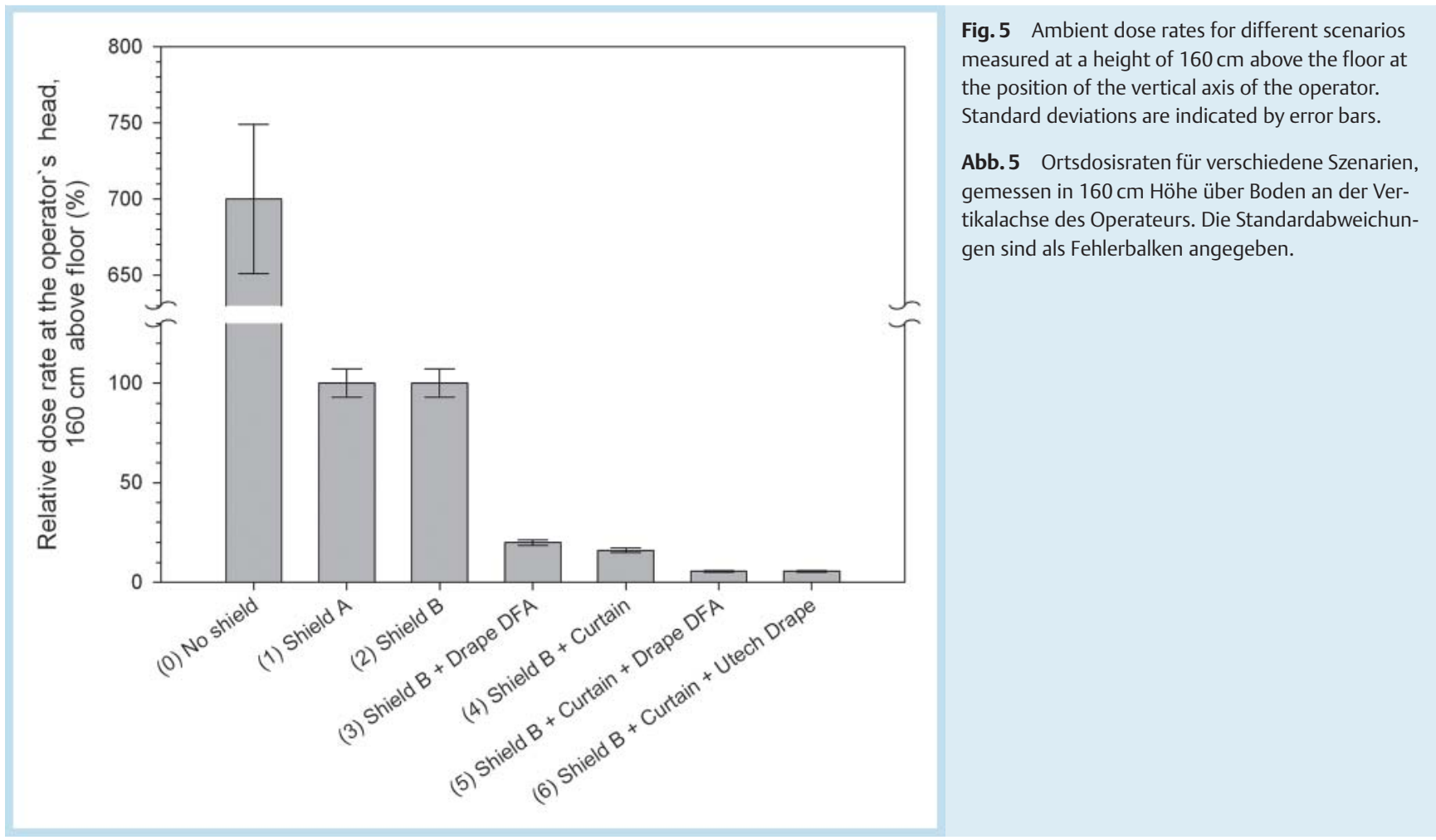

a considerable effect in dose reduction is still achieved. At a height of $160 \mathrm{~cm}$ above the floor, the following reductions were found ( $\triangle$ Table 2): For the optimized position of the drape and shield together with the curtain the exposure of the upper body of the operator reduces by nearly $(89.0 \% \pm 7.0)$. If the shield is applied with the curtain only, the exposure reduces - compared to the bare shield - by $(84.0 \% \pm 7.1)$. If the bare shield is applied with the patient drape, the exposure drops also by $(84.0 \% \pm 7.1)$.

A comparative test with the longer Utech drape could not confirm an additional reduction effect with respect to the operator's exposition compared to the smaller DFA and DRA drapes (t-test see discussion).

\section{Horizontal dose profile}

The horizontal ambient dose rate distribution $160 \mathrm{~cm}$ above the floor yields nearly identical dose profiles for shields A and B in the mid-region (vertical axis of the operator). However, larger shield B shows considerably lower dose rates in the outer range and hence provides better protection if standing more laterally ( $\bullet$ Fig. 6). A co-operator or assistant standing near the chief op- 


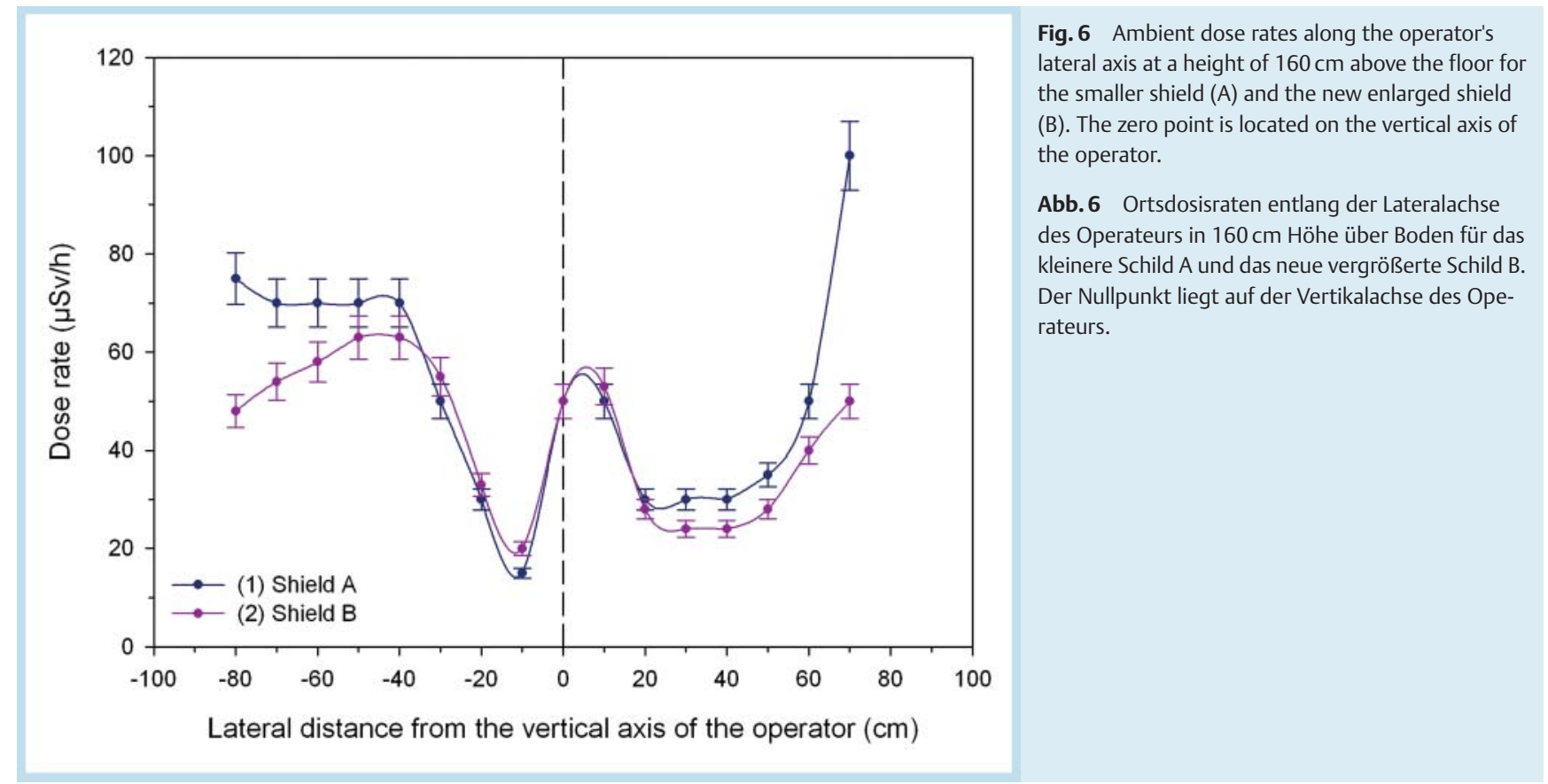

erator has a 20 - $30 \%$ lower exposure than when using the small shield.

\section{Visualization}

- Fig. 7 displays the color-scaled distribution of relative dose values in logarithmic scale related to the maximum dose achieved within the catheterization scenario. The colors represent the absorbed dose rates in air and the resulting tissue absorbed dose rates within the operator's upper body and head cross sections at heights of 130 and $160 \mathrm{~cm}$. The positions of the patient phantom and of the operator's trunk were adumbrated in the figure. Results were displayed for the bare shield ( $\bullet$ Fig. 7a, c) and the shield with the curtain ( $\bullet$ Fig. 7b, d). The colored dose distributions within the operator's body are related to the exposure rates caused by Compton scattering arising within the tissue beneath the shield and are reduced by a factor of 5-10 when using the curtain.

\section{Discussion \\ $\nabla$}

The positioning of the radiation protection components near the scattering volume of the patient leads to a substantial reduction in exposure and an advantage from an ergonomic point of view.

\section{Comparison of the scenarios Operator exposure}

The ambient dose rates $160-180 \mathrm{~cm}$ above the floor are indicative of the eye and brain dose. As already mentioned, the eye doses in interventional radiology frequently have to be rated critically with respect to international dose limits and recommendations. From - Fig. 4 the dose rates in the range of the operator's head can be read, considering four scenarios: (0) no shield, (1) bare shield $A$, (2) bare shield B, (3) shield B + drape, (4) shield B + curtain, (5) shield B + curtain and drape. A head dose reduction by up to $90 \%$ can be achieved by employing the best scenario 5 .
As can be seen from $\bullet$ Fig. 4, $\odot$ Table 2, shield B compared to shield A without any curtain or drape (as displayed in $\bullet$ Fig. 2) shows a lower exposure for a tall operator's head beginning from $180 \mathrm{~cm}$ to $200 \mathrm{~cm}$ ranging up to $33 \%$. A co-operator standing next to the operator would benefit from wider shield B. Especially the eye and head doses would be considerably reduced. In addition, the wider radiation shadow zone behind shield $B$ affects the whole interventional laboratory.

On the level of the operator's chest and head, the combination of shield B with the DFA drape (scenario 3 ) results in a dose reduction factor of 6 compared to the current standard situation with only shield A (scenario 1). Based on this scenario, shield B together with the protective curtain (scenario 4) achieves a reduction factor of 8 and shield $B$ with both protection devices (scenario 5) leads to a reduction factor of 10 compared with the ongoing standard. $\bullet$ Table 3 shows the results of the t-test among the different scenarios for confirming the best solution. Scenarios 3 and 4 are nearly identical with respect to protection whereas scenario 5 is the best of all.

It is not recommended, however, to apply the new shield without the curtain because of the arm gap, which then would not be closed and would allow the scatter radiation to penetrate through.

The test of a longer drape (Utech drape) features no clear benefit with respect to the ambient dose rate at the position of the operator (t-test, $\bullet$ Table 3). Therefore, the caudal part of the drape from the femoral port down to the knees does not provide an additional protection effect. In contrast, the large Utech drape ranging down to the thighs complicates its quick removal especially in emergencies.

It is useful to mention that the demonstrated dose reductions are only achievable if the application of the shield and drape is correct as shown in $\bullet$ Fig. 3. The drape is to be positioned directly underneath the shield and the lamellae are to touch the surface of the patient with a minimum of about one half of their length. Otherwise, the additional protective effect can be reduced considerably. 

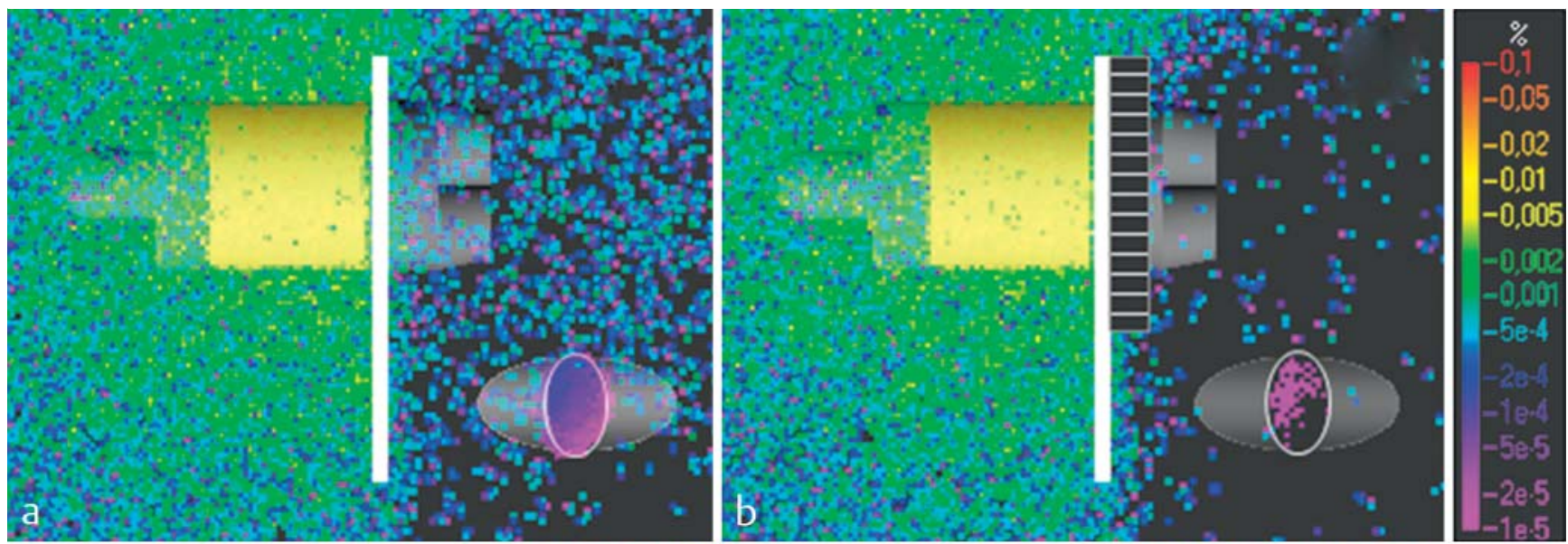

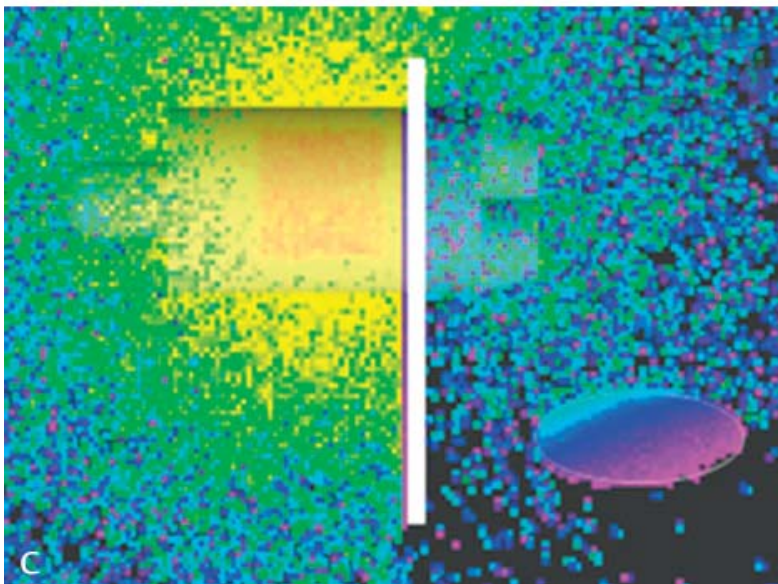

Fig. 7 Visualization by Monte Carlo simulation: top view of the standard catheterization setting with patient and operator. Colors indicate the relative absorbed dose rates in different planes above the floor, referring to the dose rate maximum in the irradiated volume. The following scenarios are displayed: a, b Plane crossing the operator's head $(160 \mathrm{~cm}$ above the floor); c, d plane crossing the operator's breast $(130 \mathrm{~cm}$ above the floor); $\mathbf{a}, \mathbf{c}$ shield without add-ons; $\mathbf{b}, \mathbf{d}$ shield with protective curtain. With curtain in situ the colors of the operator's upper body and head sections indicate an exposure reduction by a factor of $5-10$.

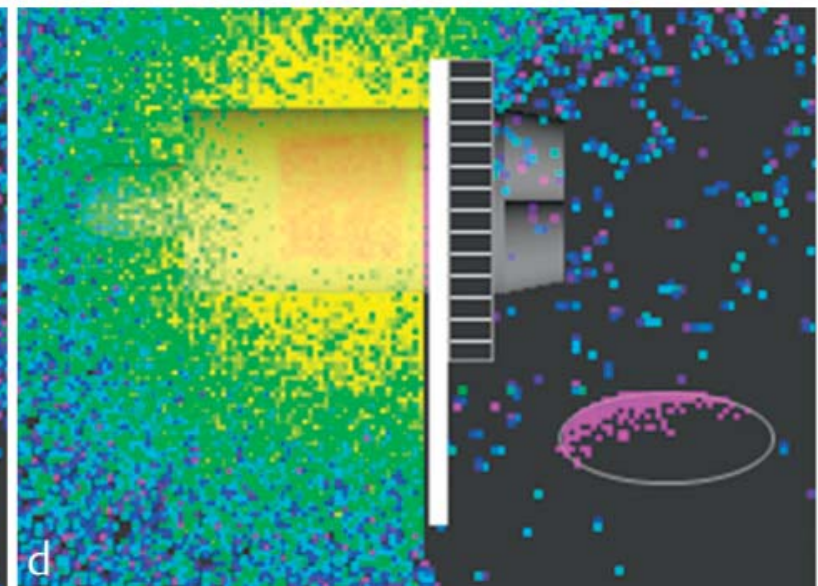

Abb.7 Visualisierung mittels Monte-Carlo-Simulation: Sicht von oben auf die Standardanordnung bei Herzkatheteruntersuchungen mit Patient und Operateur. Die Farben repräsentieren die auf die maximale Dosisrate im durchstrahlten Volumen bezogenen Energiedosisraten in verschiedenen horizontalen Ebenen. a, b Ebene auf mittlerer Kopfhöhe des Operateurs (160 cm über Boden); $\mathbf{c}, \mathbf{d}$ Ebene auf Brusthöhe des Operateurs $(130 \mathrm{~cm}$ über Boden); a, c Schild ohne Zusatz; b, d Schild mit Lamellenvorhang. Wie die Farbcodierung zeigt, bewirkt der Vorhang in situ in Brust- und Kopfhöhe eine Reduktion der Exposition um den Faktor 5 bis 10 .
Table 3 Results of the inter-scenario t-test $(p=0.05)$. Column 2: shield $B$ is only superior to shield A from 180 to $200 \mathrm{~cm}$ above the floor. Therefore, $\mathrm{H}_{0}$ (null hypothesis) is accepted.

Tab. 3 Ergebnisse des t-Tests zwischen den Szenarien $(p=0,05)$. Spalte 2: Schild B ist nur über $180 \mathrm{~cm}$ Höhe besser als Schild A, deshalb wird die Nullhypothese $\mathrm{H}_{0}$ bestätigt.

\begin{tabular}{llllll}
$\begin{array}{l}\text { scenarios } \\
\text { compared: }\end{array}$ & 1 vs. 2 & 3 vs. 4 & 3 vs. 5 & 4 vs. 5 & 5 vs. 6 \\
t-value & 0.13 & 0.20 & 8.5 & 10.1 & 2.12 \\
\hline rating & $\begin{array}{l}\mathrm{H}_{0} \\
\text { accepted } \\
\text { (no diff.) }\end{array}$ & $\begin{array}{l}\mathrm{H}_{0} \\
\text { accepted } \\
\text { (no diff.) }\end{array}$ & 5 superior & 5 superior & $\mathrm{H}_{0}$ \\
accepted & & & \begin{tabular}{l} 
(no diff.) \\
\hline
\end{tabular}
\end{tabular}

\section{Assistants}

From the physical point of view, the assistant is affected in the same manner as the operator from the radiation "undercutting" effect occurring on the lead acrylic shield. It follows that the relative exposure is reduced by nearly the same amount as for the operator. According to $\bullet$ Table 2 , the dose reduction on the upper body of the assistant standing near the examiner amounts to
$(92 \% \pm 7.0)$. At a height of $80 \mathrm{~cm}$ above the floor, the reduction is in a range of $30 \%$.

\section{Clinical application aspects \\ Positioning}

A study dealing with the usability and protection of the new shield in the clinical environment is currently in progress. The final results of this study will be published independently. However, the following point that needs to be paid special attention to when transferring the results from this phantom study to the clinical practice has already been noticed:

The most important requirement for a decrease in radiation of the magnitude seen in this study is that the shield is placed correctly. It is crucial that the protective curtain lies flat on the patient. As soon as the patient is moved during an intervention without repositioning of the shield, the physician will probably not be as protected as before. Due to a smaller portion of the protective curtain lying flat on the patient, more scattered radiation can pass underneath the shield.

However, this diligent repositioning of the shield can be avoided if a radiation protective drape is used in combination with the 
shield (scenario 5, $\bullet$ Fig. 3). With this combination, even if the protective curtain of the shield does not lie perfectly flat on the patient anymore, the physician is still protected by the drape. The drape extends the protective area of the curtain, and thus simulates a continuous flat-lying curtain lying flat.

\section{Angulation}

The special pattern of the drape was designed to avoid interference with the imaging system when the C-arm is angulated. In order to avoid interference with the dominant of the automatic exposure control (AEC) system during the application of the drape, the center dominant of the image detector should be chosen. In this mode, even though the drape appears on the border of the monitor, the dose rate will not rise automatically. At C-arm angulations of RAO 45 and higher, collisions between the detector and shield can occur. In practice the operator will then move the shield slightly laterally. To date, in clinical practice, significant problems due to interference between the shield and detector have rarely been observed.

\section{Influence of detector/field size}

Concerning the application of our results to other laboratories, for the dose reduction at the position of the operator and the assistant, the size of the detector, i.e. its outer dimension, is very important. A larger detector, especially in combination with a smaller field, can reduce scatter radiation in the direction of the upper body of the operator/assistant and shows a kind of "selfprotecting" effect.

Therefore, the additional effect of the protective curtain and the drape can be smaller than measured here when applying a large detector especially with a smaller field size.

\section{Application for radial access}

For the access via the radial artery, an alternative setup can be chosen. The shield in this case is positioned next to the patient, the patient's arm passing through the bigger of the two gaps of the shield ( $\bullet$ Fig. 8). The drape remains on the pelvis as shown in - Fig. 3. This setup may be beneficial with respect to angulation of the C-arm. Concerning the operator, this arrangement is as effective as that shown in 0 Fig. 3 but may have one disadvantage: the doses at the site of the assistant personnel may increase. Hence, additional protection aspects should be considered for the assisting staff.

\section{Sterility aspects}

Prior to clinical procedures, the drape and acrylic shield with a curtain can be inserted into custom-made sterile covers. These covers have to be applied by the scrub assistant who scrubbed prior to the procedure. The drape may be positioned under or on top of the sterile patient cover. Removal, in the case of clinical need, can be easily facilitated using the on top position.

\section{Protection aspects}

The necessity of the described protection devices may be questioned since the staff already wear X-ray-protective clothing. It can be argued, however, that relevant biological tissues or parts of the body such as the head (eye lenses and brain) remain unprotected. From the ergonomic viewpoint, when using the optimized shield and drape, lighter protective clothing may be used. Instead of the frequently used aprons with a lead equivalence value of $0.5 \mathrm{~mm}$, protective clothing with $0.35 \mathrm{~mm}$ featuring $30 \%$ lower weight can be worn.

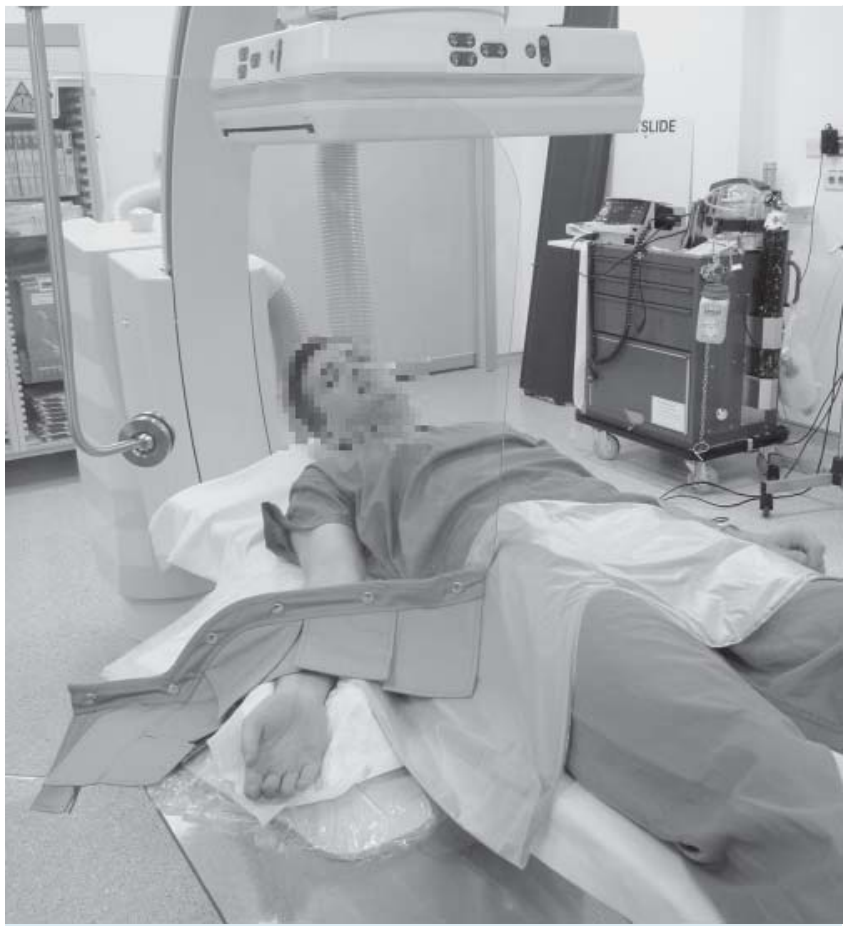

Fig. 8 Alternative setting of the shield during access to the wrist (radial artery). The patient was represented by a member of our staff (simulated situation without application of radiation).

Abb. 8 Alternative Anordnung des Schildes beim radialen Zugang. Der Patient wurde hier durch eine Person aus dem Kreis der Beschäftigten verkörpert (Simulation ohne Anwendung von Strahlung).

\section{Conclusion}

$\nabla$

As a result it can be stated that with application of the improved protection devices described here, important radiation protection benefits for clinical practice can be achieved.

\section{Acknowledgements \\ $\nabla$}

We are grateful to the management of the Cathlab of Mater Private Hospital, Dublin, for granting the application test. We would also like to thank the director of the Cathlab of the German Heart Centre of the State of Bavaria, Munich, for authorizing the physical measurements. In addition, we would also like to thank Siemens Healthcare (Germany) and Mavig GmbH (Munich, Germany) for supporting the tests by the necessary equipment.

Conflict of Interest: Author \#1 declares: Mavig provided the protection devices used during the dose measurements. Author \#2 declares that no conflicts of interest exist. Author \#3 declares that no conflicts of interest exist. Authors \#4 declares: Mavig and Siemens loaned us the shield/ drapes and an electronic dose monitoring system was loaned from Raysafe and was later purchased by the hospital at market value. 


\section{References}

1 Faulkner K. Radiation protection in interventional radiology. Brit J Radiol 1997; 70: 325-326

2 Johnson D, Kyriou J, Morton EJ et al. Radiation Protection in Interventional Radiology. Clinical Radiology 2001; 56: 99-106

3 Kuipers G, Verlders X. Effective dose to staff from interventional procedures: Estimations from single and double doismetry. Radiat Prot 2009; 136: $95-100$

4 Schueler BA, Vrieze TJ, Bjarnason $\mathrm{H}$ et al. An Investigation of Operator Exposure in Interventional Radiology. RadioGraphics 2006; 26 : $1533-1541$

5 Vano E, González L, Fernandez JM et al. Occupational radiation doses in interventional cardiology: a 15-year follow-up. Brit J Radiol 2006; 79: $383-388$

6 Verordnung über den Schutz vor Schäden durch Röntgenstrahlung RöV. BGBl. I 2003: 604, geändert 2011 BGBl. I:2000

7 ICRP International Commission on Radiation Protection. Statement on Tissue Reactions. ICRP 2011, ref 4825-3093-1464 http://www.icrp. org/docs/icrp\%20statement\%20on\%20tissue\%20reactions.pdf

8 Council Directive 2013/59/EURATOM. Brussels: European Union; 2013

9 Donnadille L, Carinou E, Brodecki $M$ et al. Staff eye lens and extremity exposure in interventional cardiology:Results of the ORAMED project. Radiation Measurements 2011; 46: 1203-1209

10 Sandblom V, Lundh C, Cederblad Å et al. Evaluation of eye lens doses received by medical staff working in interventional radiology at Sahlgrenska University Hospital; 2012, http://www.gu.se/digitalAssets/ 1360/1360091_viktor-sandblom-rapport.pdf

11 Richtlinie für die technische Prüfung von Röntgeneinrichtungen und genehmigungsbedürftigen Störstrahlern (SV-RL) vom 9.1.2009 (mit Änderungen)
12 Interventionelle Radiologie. Empfehlung der Strahlenschutzkommission; 2008; Heft 56

13 Schulz E, Melchert UH, Stöckelhuber BM. Arten und Wirkung von Strahlenschutzzubehör, Kongressbeitrag. Fortschr Röntgenstr 2006; 178

14 Ertel A, Nadelson J, Shroff AR et al. Radiation Dose Reduction during Radial Cardiac Catheterization:Evaluation of a Dedicated Radial Angiography Absorption. International Scholarly Research Network ISRN Cardiology 2012 Article ID 769167, 5p.

15 Lange HW, von Boetticher H. Reduction of Operator Radiation Dose by a Pelvic Lead Shield during Cardiac Cathterization by Radial Access. JACC Cardiovascular Interventions 2012; 5: 445-449

16 Politi $L$, Nocetti $L$, Biondi-Zoccai $G$ et al. Reduction of scatter radiation during transradial percutaneous coronary angiography: A randomized trial using a lead-free radiation shield. Cathederization and Cardiovascular Interventions 2012; 79: 97 -102

17 Utech A, Schulze R, Sievert $H$. Eine neue Strahlenschutzvorrichtung für interventionell tätige Kardiologen. Zeitschrift für Kardiologie 1993: 82

18 Physikalisch-Technische Bundesanstalt. Neue Dosis-Messgrößen im Strahlenschutz, PTB-Dos-23; 1994

19 Kleinschmidt C. EGS-Ray, ein Programm zur Visualisierung von MonteCarlo-Rechnungen in der Strahlenphysik. Z Med Phys 2001; 11: 119123

20 Nelson WR, Hirayama H, Rogers DWO. The EGS4 System, Version4. Stanford Linear Accelerator Center Report 1985: 265

21 Birch R, Marshall M. Computation of bremsstrahlung X-ray spectra and comparison with spectra measured with a $\mathrm{Ge}(\mathrm{Li})$ detector. Phys Med Biol 1979; 24: 505-517 